\title{
Technological Formation Scale for Teachers (TFS): Development and Validation
}

\author{
Cavit Erdoğmuş ${ }^{*}$ \\ Amasya University, Graduate School of Natural and Applied Sciences, Department of \\ Computer Education and Instructional Technology, Amasya, Turkey \\ ORCID: 0000-0002-6717-0528 \\ Emre Çoban \\ Amasya University, Graduate School of Natural and Applied Sciences, Department of \\ Computer Education and Instructional Technology, Amasya, Turkey \\ ORCID: 0000-0001-9142-3858
}

\author{
Özgen Korkmaz \\ Amasya University, Faculty of Technology, Department of Computer Engineering, \\ Amasya, Turkey \\ ORCID: 0000-0003-4359-5692
}

\begin{abstract}
M. Yaşar Özden
Eastern Mediterranean University, Faculty of Education, Department of Computer Education and Instructional Technology, Famagusta, TRNC, KKTC
\end{abstract}

ORCID: 0000-0001-6976-7822

\begin{tabular}{ll}
\hline \hline Article history & The aim of this study is to develop a valid and reliable Technological \\
\hline Received: & Formation Scale to measure Technological Knowledge (TK) and \\
10.11 .2020 & Technological Pedagogical Knowledge (TPK) which are main \\
Received in revised form: & components of Technological Pedagogical Content Knowledge \\
09.12 .2020 & (TPACK). Technology seems to have an important place in teacher \\
& training and education. It is seen that only Pedagogical Content \\
Accepted: & Knowledge (PCK) is not sufficient today. Therefore, the measurement \\
11.12 .2020 & tools including 21st century requirements which are the information and \\
& communication technologies skills, production and productive thinking \\
Key words: & are needed. Measuring technological and technological pedagogical \\
Technological formation, & knowledge of the teachers and teacher candidates is able to be possible by \\
Teacher competence, & means of this measurement tool. Another aim of this study is to present a \\
Productive thinking & measurement tool within the TPACK framework, which is based on \\
& productivity for the researchers. The components of Technological \\
& Knowledge (TK) and Technological Pedagogical Knowledge (TPK) \\
involve the productive thinking in this scale. Thus, it is aimed to obtain \\
real-like results. The participants were 756 teachers and and teacher
\end{tabular}

\footnotetext{
* Correspondency: caviterdogmus@gmail.com
} 
candidates from different regions of Turkey. Structure validity, item factor correlations, item discrimination, internal consistency and stability levels reveal that Technological Formation Scale is a valid and reliable measurement tool. As a result of the validity and reliability analysis, the scale has a 4-factor structure, namely "Content Development", "Interactive Object Development", "Problem Solving" and "Creativity" under the main headings of Production and Productive Thinking. While the reliability value of the whole scale is .972 , the values of the factors are $.972, .973, .937$ and .850 , respectively.

\section{Introduction}

Technological Pedagogical Content Knowledge (TPACK) is a teacher training approach based on Pedagogical Content Knowledge (PCK) by Shulman (1987, 1986) for teachers to produce effective teaching with instructional technologies. The understanding of TPACK was developed with a series of studies by Mishra and Koehler (2006) and Koehler and Mishra (2009). This approach contains three main teacher knowledge domain. These knowledges are content, pedagogic and technology (See also Figure 1). These knowledges can interact with each other such as Technological Pedagogical Knowledge (TPK), Pedagogical Content Knowledge (PCK), and Technological Content Knowledge (TCK). The components are presented in Figure 1.

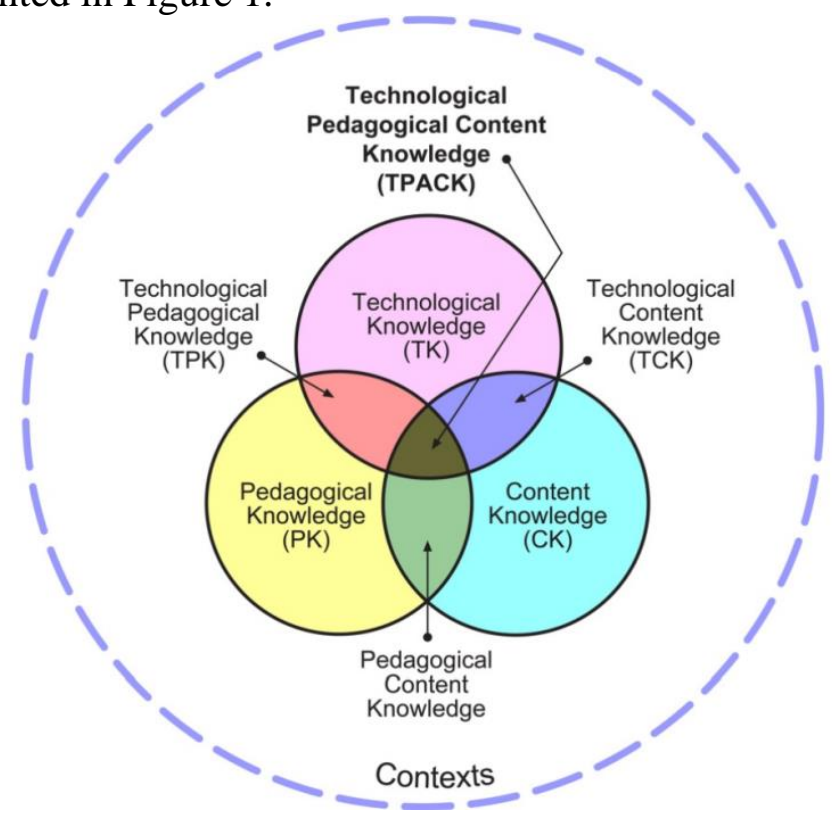

Figure 1. The TPACK framework and its knowledge components (Koehler \& Mishra, 2009).

The summary of the components is as follows: Content Knowledge: To give specific information on a subject without pedagogical activities (Cox \& Graham, 2009). Pedagogical Knowledge: "To focus on a teacher's knowledge of the general pedagogical activities that he/she might utilize" (Cox \& Graham, 2009). Technological Knowledge: "It is defined as the knowledge of how to use emerging technologies" (Cox \& Graham, 2009). Technological Content Knowledge: "Demonstrations of exemplar teaching/learning resources produced by using different software applications" (Hu \& Fyfe, 2010). Pedagogical Content Knowledge: "To design tasks that require students to connect what they do in information and communication technology unit to what they have learned in their curriculum subject areas" (Hu \& Fyfe, 2010). Technological Pedagogical Knowledge: "To design tasks in which 
students works in pairs, exploring the affordances of information and communication technology tools of their choice to address a particular teaching/learning need" (Hu \& Fyfe, 2010). Technological Pedagogical Content Knowledge: “A teacher's knowledge of how to coordinate the use of subject-specific activities or topic-specific activities with topic-specific representations using emerging technologies to facilitate student learning" (Cox \& Graham, 2009). In brief, Technological Knowledge (TK) and Technological Pedagogical Knowledge (TPK) are required for Technological Formation. Technological Content Knowledge (TCK) contains technology itself and its utilization for production purposes and Technological Pedagogical Knowledge (TPK) describes how to use technology in the teaching/learning process (Özden, 2012).

It can be said that teachers have different competences without TPACK as well as Content Knowledge to make an effective classroom environment based on the components. The tools in field of education such as online courses are being changed together with renewed technological developments (Bulman \& Fairlie, 2016). As a result of these, there have been a series of changes such as the transition from blackboard to interactive boards (Adigüzel, Gürbulak \& Sarıçayır, 2011). Due to these kind of changes, teachers' technological proficiencies have become important (Voogt \& McKenney, 2016). Countries update their educational policies to determine these proficiencies. Technology policies in education is being developed to catch rapidly emerging technologies, and to complete the necessities of the era (Tekin \& Polat, 2014). There are important tasks that fall on teachers to apply technology in education as a result of these developments. In addition, school administrators should have these proficiencies such as supporting teachers' use of technology in lessons, helping them develop e-content and maintaining their personal development (Bakioğlu \& Şentuna, 2001).

The implementation of technological developments in education in Turkey is done with the Turkey Informatics Councils, the Vision 2023 Strategy Paper, National Education Councils and the Increasing Opportunities Improving Technology Movement (FATIH) Project with these endeavours, studies are developed to integrate technology with Turkish educational institutions and educational system (Tekin \& Polat, 2014). Many reforms have been applied such as using information technology tools in education, improvement of infrastructure, synchronous working, and to produce digital contents (Tekin \& Polat, 2014). For this reason, not only the policies, proficiencies of the teachers and the managers, who work for educational institutions, also are important for these policies to apply and to process (Bakioğlu \& Şentuna, 2001). The Ministry of National Education (MoNE) carries on periodic studies about determining teaching profession's proficiencies.

Basic policies related to education and profession of teaching of international organizations such as Council of Europe, the World Bank, ILO, OECD, UNESCO and UNICEF and proficiency documents of several countries like USA, Australia, Finland, France, Hong Kong, UK, Canada and Singapore were analysed to form these proficiencies. As a result of these studies, the General Competencies of Teaching Profession was published by Directorate of Teacher Training and Development, the MoNE in 2017. It contains three proficiency fields: "professional knowledge", "professional skill", "attitude and values" which are interrelated and mutually complementary, and 11 proficiencies under them and 65 indicators of these proficiencies. These proficiencies are named as follows: "subject area knowledge", "subject area teaching knowledge", "legislation knowledge", "education planning", "making learning environment", "managing teaching and learning process", "national, spiritual and universal values", "assessment and evaluation", "approach to a student", "communication and 
cooperation" and "personal and professional development" (MoNE, 2017). Besides all of these, in a study, which is related to in-service training requirements in the field of instructional technology, it is found that teachers mostly need in-service training in "Using Technology in Education", "Effective Use of Teaching Materials" and "Use of the Internet for Education" topics (Sarıtepeci, Durak \& Seferoğlu, 2016).

In a study by McKnight et al. (2016), technology increases ease of access for both teachers and students, increases communication and feedbacks, leads to a restructuring of teachers' time and shows changes in student and teacher roles. Specially, blended learning and flipped learning with technology, provides access to more resources and broad opportunities for students. However, when the literature is examined, it is emphasized that teachers' technology skill levels may be an obstacle for technology integration (Carver, 2016). In the study conducted by Moradi-Rekabdarkolaei (2011) with 384 secondary school students and 367 teachers, as a result of evaluating the participants' critical thinking, problem solving and cognitive levels, it was found that students differ significantly in terms of access, management, integration, evaluation and producing content than teachers.

Considering these findings in the literature, it can be said that the integration of teachers and teacher candidates into technology will become more important for future education programs. Therefore, the Technological Knowledge component in the TPACK framework plays a key role for effective learning models, increasing the communication between teacher and students, efficient use of time, adaptation to the digital age, and more similar variables are effective. In the literature, scales for different dimensions of TPACK have been developed regarding these components (Timur \& Taşar, 2011; Gökçek \& Y1lmaz, 2019; Usta \& Karakuş, 2016; Hiçyılmaz, 2018, Özel, Timur, Timur \& Bilen, 2013). When the scales with technological components are examined, the scales have been developed or adapted for a specific field (such as classroom teaching only) (Kaya, Kaya \& Emre 2013; Haciömeroğlu et al., 2014; Önal, 2016; Sarı \& Bostancıŏlu, 2018).

Another common point of the examined scales is that they are for the use of education technologies. However, with the rapidly-developing technology, it is known that users are not only accessing information but also produce content. Even Web 2.0 technologies, which are an example of this, appear to be moving far ahead from Web 3.0 (Semantic Web) (Yağc1, 2011). In this context, technology in other words, information sources are not only an environment created by experts but have become platforms that develop and produce information with users. In a study conducted with teachers on the example of Web 2.0 technologies, it is stated that teachers feel better about using technology with Web 2.0 technologies and they see themselves differently from other teachers (Tatli, İpek Akbulut \& Altınış1k, 2016). Platforms with Web 2.0 technologies appear to play a new role in transformation of teaching and learning (Alexander \& Levine, 2008). Activities such as collaborating with Web 2.0 technologies, actively participating in content creation, generating information and sharing information online have been emerged (Grosseck, 2009). By means of the activities, it allowed students to become content producers rather than just listening to lectures. In the same time with Web 2.0 technologies, teachers are transformed into people who produce content to facilitate learning more than an information distributor (An \& Williams, 2010). Thus, students are at the heart of the learning process (Palaigeorgiou \& Grammatikopoulou, 2016). Researchers emphasizes that for Web 2.0 technologies to be effective, content must be produced by users who use it (Rahimi, van den Berg \& Veen,2015; Al-Qallaf \& Ridha,2018). In an environment where students produce content, it is inevitable for teachers to produce information. In an environment where Web 4.0 is on the agenda 
(Yağc1, 2011), teachers need to be involved in the production process for technologies like Web 2.0 to be effective (Okello-Obura \& Ssekitto, 2015). Due to developing technology and increasing use of information and communication resources, the change of traditional teaching methods made it necessary for teachers to be productive individuals in order to remain effective in teaching processes (Thomas \& Thomas, 2012).

Consequently, due to the above stated reasons, in the literature, no validated and reliable measurement tool has been found to measure the Technological Knowledge levels independently based on the competence of teachers and teacher candidates to use technology as a production tool. Accordingly, the aim of this research is to develop a valid and reliable Technological Formation Scale that measures the ability to use technology as a production tool.

\section{Method}

\subsection{Research Model}

This research that uses descriptive survey model is a scale development study. In survey model, information is collected from a wide audience, using answer options determined by the researcher. Generally, in survey research, researchers are concerned with how opinions and characteristics are distributed in terms of individuals in the sample rather than why they originate (Fraenkel \& Wallen, 2006).

\subsection{Sample}

The study group of the research consisted of 672 teachers who are working at Ministry of National Education and 84 teacher candidates who were study at a medium-sized university located in Black Sea Region, Turkey. The participants in the research were from different subject area such as Computer Education, Maths, Science, Classroom Teaching etc. The 24 random participants in the study group were selected again to test the stability of the scale. Descriptive explanation of the study group was showed in Table 1 by gender, subject area and experience

Table 1. Descriptive explanation by gender, department, experience.

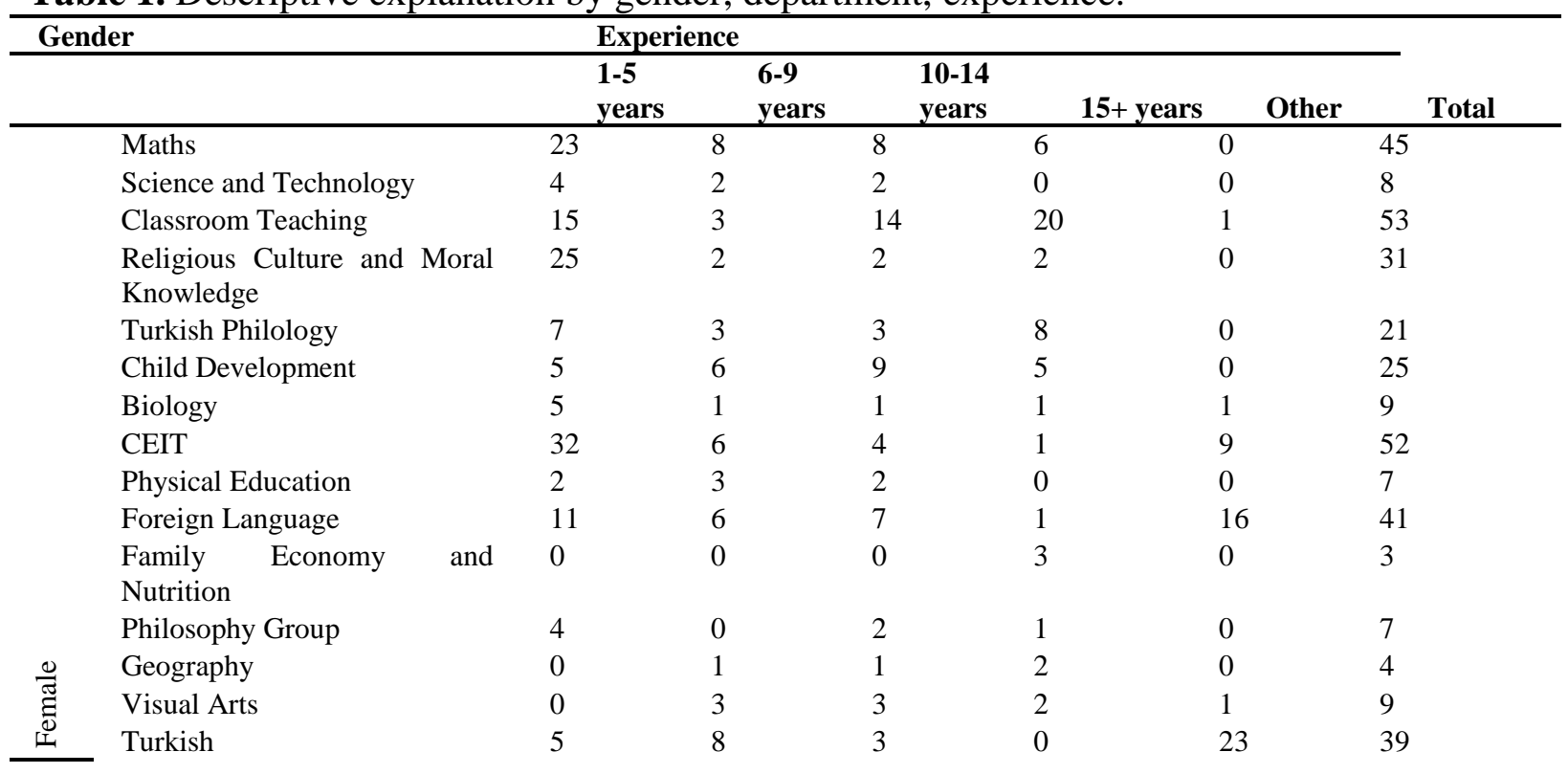




\begin{tabular}{|c|c|c|c|c|c|c|c|}
\hline & History & 3 & 0 & 1 & 5 & 0 & 9 \\
\hline & Social Studies & 2 & 2 & 2 & 1 & 0 & 7 \\
\hline & Vocational Lessons & 1 & 2 & 2 & 10 & 0 & 15 \\
\hline & Music & 1 & 1 & 0 & 0 & 0 & 2 \\
\hline & Chemistry & 4 & 1 & 1 & 1 & 0 & 7 \\
\hline & $\begin{array}{l}\text { Psychological Counselling and } \\
\text { Guidance }\end{array}$ & 2 & 2 & 0 & 0 & 0 & 4 \\
\hline & Other & 12 & 3 & 4 & 9 & 0 & 28 \\
\hline & Physics & 1 & 1 & 0 & 2 & 0 & 4 \\
\hline & Total & 164 & 64 & 71 & \multirow{2}{*}{$\begin{array}{l}80 \\
6\end{array}$} & 51 & 430 \\
\hline & Maths & 6 & 4 & 6 & & 1 & 23 \\
\hline & Science and Technology & 1 & 1 & 5 & 3 & 0 & 10 \\
\hline & Classroom Teaching & 4 & 5 & 11 & 32 & 0 & 52 \\
\hline & $\begin{array}{l}\text { Religious Culture and Moral } \\
\text { Knowledge }\end{array}$ & 2 & 1 & 3 & 13 & 0 & 19 \\
\hline & Turkish Philology & 0 & 2 & 4 & 13 & 0 & 19 \\
\hline & Child Development & 0 & 1 & 0 & 3 & 0 & 4 \\
\hline & Biology & 0 & 0 & 1 & 1 & 0 & 2 \\
\hline & CEIT & 15 & 5 & 4 & 3 & 7 & 34 \\
\hline & Physical Education & 1 & 7 & 6 & 4 & 1 & 19 \\
\hline & Foreign Language & 2 & 2 & 3 & 6 & 4 & 17 \\
\hline & $\begin{array}{l}\text { Family Economy and } \\
\text { Nutrition }\end{array}$ & 0 & 0 & 1 & 0 & 0 & 1 \\
\hline & Philosophy Group & 0 & 1 & 0 & 1 & 0 & 2 \\
\hline & Geography & 1 & 0 & 1 & 2 & 0 & 4 \\
\hline & Visual Arts & 2 & 0 & 1 & 0 & 0 & 3 \\
\hline & Turkish & 1 & 3 & 6 & 6 & 19 & 35 \\
\hline & History & 0 & 1 & 1 & 11 & 0 & 13 \\
\hline & Social Studies & 0 & 1 & 6 & 6 & 0 & 13 \\
\hline & Vocational Lessons & 2 & 3 & 3 & 17 & 0 & 25 \\
\hline & Chemistry & 0 & 0 & 0 & 2 & 0 & 2 \\
\hline & $\begin{array}{l}\text { Psychological Counselling and } \\
\text { Guidance }\end{array}$ & 0 & 0 & 1 & 5 & 0 & 6 \\
\hline & Other & 2 & 1 & 2 & 12 & 0 & 17 \\
\hline$\frac{0}{\pi}$ & Physics & 0 & 0 & 0 & 5 & 1 & 6 \\
\hline$\Sigma$ & Total & 39 & 38 & 65 & 151 & 33 & 326 \\
\hline & General Total & 203 & 102 & 136 & 231 & 84 & 756 \\
\hline
\end{tabular}

\subsection{Development Process of the Scale}

In order to establish an item pool, first of all, literature review was conducted to reveal the meaning of technological formation (Cox \& Graham, 2009; Hu \& Fyfe, 2010). Then, literature was examined about the knowledge of technological formation of teachers (Bulman \& Fairblie, 2016; Adıgüzel, et al., 2011; Voogt \& McKenney, 2016; Tekin \& Polat, 2014; Bakioğlu \& Şentuna, 2001). In order to determine competencies, the basic policies of international organizations such as the Council of Europe, the World Bank, ILO, OECD, UNESCO and UNICEF regarding education and teaching and the proficiency documents of many different countries such as USA, Australia, Finland, France, Hong Kong, Great Britain, Canada and Singapore were examined (MoNE, 2017). A literature review was conducted to determine how information technologies and internet technologies should be used in educational environments (McKnight et al., 2016; Carver, 2016; Saritepeci et al., 2016). Finally, it was decided what kind of information the teachers should have in order to use information technologies and internet technologies. Accordingly, in order to form an item pool, the literature was examined, and the item pool was formed with the information obtained (Sarı \& Bostancığlu, 2018; Önal, 2016; Okello-Obura \& Ssekitto, 2015; Haciömeroğlu, 2014; Kaya et al., 2013; Thomas \& Thomas, 2012; Yağc1, 2011; An \& Williams, 2010; Grosseck, 2009; Alexander \& Levine, 2008). In addition, considering the 
necessity of thinking skills in the use of technology in the production process, it was thought that teachers should have computational thinking skills in order to produce (Özden, 2015). Within this framework the computational thinking scale developed by Korkmaz, Çakır and Özden (2017) was examined and 15 items of this scale were considered appropriate to be taken into the item pool.

According to the information obtained from the literature review 71 items were included in the item pool. The scope validity of the item pool was rearranged by taking the opinions of 4 faculty members who are experts in the field of education in the from two different universities in order to control their appropriateness with the required properties and the measured properties. According to the feedback given by the experts, incorrect or difficult to understand statements were corrected and 3 items were removed from the item pool. As a result of the updates, the final item pool was emerged. Thus, a "Technological Formation Scale" trial form with 68 items was created. The scale, which was prepared as a 5-Likert type scale, was named as (1) Strongly Disagree, (2) Disagree, (3) Undecided, (4) Agree and (5) Strongly Agree.

\subsection{Data Analysis}

In the data analysis process first, the negative items 32., 41., 49. were calculated by reverse scoring during the analysis process. Then, the data were analysed with SPSS package program. Next, validity and reliability analyses were performed on the obtained data. KMO and Bartlett Test were used to determine the suitability of the scale for factor analysis. It was decided to carry out factor analysis because the values were found to be appropriate. Russell (2002) states that KMO value is above 0.90 is suitable for the factor analysis of the scale. Furthermore, according to Bartlett test results, it is said that $\mathrm{H}_{0}$ was rejected when the statistical significance value was at 0.05 level (Büyüköztürk, 2002; Eroğlu, 2008). Then, an exploratory factor analysis was conducted to determine the construct validity and factor structure of the scale. Factor analysis is a statistical technique that aims to explain the measurement with a small number of factors by combining variables that measure the same structure or quality (Büyüköztürk, 2006). While describing the construct validity, Büyüköztürk, Çakmak, Akgün, Karadeniz and Demirel (2016) emphasized how accurately the scale items can measure the concept being tried to be measured. The construct validity of the scale was tested with exploratory factor analysis, item discriminant analysis and item total correlation analysis.

Factor loads were calculated by using Varimax vertical rotation technique in order to divide the scale items into factors. The calculation of factor loads is the main criterion for determining and interpreting the factors (Balc1, 2009). If the correlation of each item of the factor with that factor is greater than \pm 0.30 , it is accepted that there is a significant relationship between that item and the factor it belongs to. (Turanl, Cengiz \& Bozkir, 2014). According to the Principal Component Analysis, the factor load was below 0.30 and the items distributed to multiple factors were identified and discarded. Finding the least number of factors that best represent the relationship between the items is the main purpose in factor determination (Kalayc1, 2006). $40 \%$ of the total variance of each factor is sufficient to find the appropriate number of factors (Büyüköztürk, 2002; Eroğlu, 2008).

After factor analysis, an independent sample t-test was performed to determine the distinctiveness of the items. In order to determine the validity of the scale, Pearson's' $r$ test was used to determine item total correlations. Thus, it was found out to what extent each item 
supports the factor involved. In order to determine item discrimination, the total scores of each item were ordered from largest to smallest, then the upper and lower $27 \%$ groups were formed. The extent of differentiation between these groups was determined. Stability tests and internal consistency were used to determine the reliability of the scale. For internal consistency coefficient, Cronbach Alpha was considered. The reliability coefficient is 0.70 and above, indicating that the scale is reliable (Kartal \& Dirlik, 2016). Scale reliability was also supported by Guttman Split-Half, Sperman-Brown tests and two paired semi-correlation formulas. Test-retest was used to analyse the stability of the scale. Therefore, scale items were applied to 24 participants at 4 -week intervals and the correlation values between the two data groups were examined.

\subsection{Data Collection}

Online and printed forms were used to reach teachers who work all over the Turkey. In order to get more participants with the online form, information was shared in social groups created for teachers and prospective teachers via Facebook. The printed form was used to reach the participants in the institutions and the universities. The data obtained with printed forms were transferred to digital form.

\section{Findings}

\subsection{Findings Regarding the Validity of the Scale}

The scale' construct validity, item-factor correlations and item discrimination values were examined for the validity of the Technological Formation Scale. The findings are presented below.

\subsubsection{Construct Validity (Exploratory Factor Analysis):}

First, Kaiser-Meyer-Olkin (KMO) and Bartlett tests were carried out to determine the construct validity of the technological formation scale. As a result of the analysis, KMO = 0.968 , Bartlett test was found to be $\chi^{2}=39783.238, S D=1485,(p=0.000)$. Within the framework of these values, it was observed that the 68-item scale was suitable for factor analysis. Then, the scale factorization status was determined by Varimax vertical rotation technique. Varimax vertical rotation technique was carried out 4 times for factor analysis according to item load conditions and item distribution conditions. In the first analysis, a 4factor structure emerged and items 1, 2, 4, 32, 41 and 49 were removed from the item pool as they were distributed to more than one factor. As a result of the second factor analysis, a 4factor structure emerged. Since, item 5 was divided into multiple factors; the item was removed from the scale. In the third factor analysis, again, a 4-factor structure was obtained and items 15, 16, 39, 40 and 61 were removed from the scale as they were distributed to more than one factor. In the last factor analysis, item 16 was removed from the item pool and the scale was composed of 4 factors. After the Varimax vertical rotation technique, the factor loadings of the 4 factors scale were found to be between 0.810 and 0.543 . In addition, $62.544 \%$ of the total variance of items and factors explained. The distribution of scale factors is shown in Figure 2. 


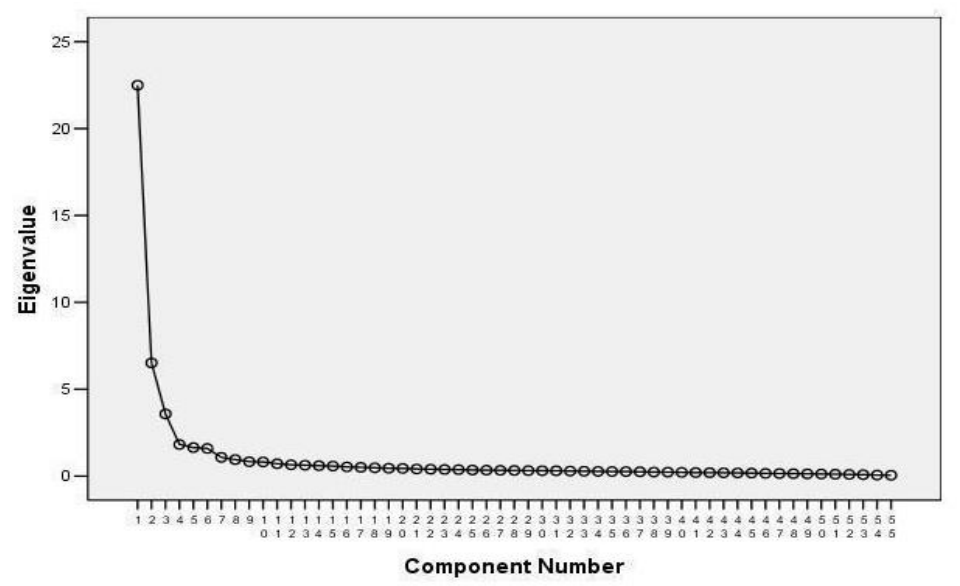

Figure 2 Eigenvalues - Factors

When Figure 2 is examined, the slope flattens after the 4th point. This shows that the scale has 4 factors. As a result of these analyses to determine the factors and scale items, the findings regarding the item loads, eigenvalues and variance explanation of the 55 items in the scale are presented in Table 2.

Table 2. Results of Exploratory Factor Analysis

\begin{tabular}{|c|c|c|c|c|c|}
\hline Items & Com. & F1 & $\mathbf{F 2}$ & $\mathbf{F 3}$ & F4 \\
\hline $\begin{array}{l}\text { 14. I can make online educational media (animation, video, educational } \\
\text { game). }\end{array}$ & .764 & .785 & & & \\
\hline $\begin{array}{l}\text { 13. I can fictionalize an educational media (animation, video, } \\
\text { educational game) step by step. }\end{array}$ & .735 & .776 & & & \\
\hline 25. I can make my custom pages on the online platforms I use. & .779 & .769 & & & \\
\hline 24. I can customize the software I use by my needs. & .761 & .755 & & & \\
\hline $\begin{array}{l}\text { 07. I can make a blog or blogs which my students discuss and submit } \\
\text { ideas. }\end{array}$ & .717 & .749 & & & \\
\hline $\begin{array}{l}\text { 23. I can prepare creative lesson content with mobile devices } \\
\text { (smartphone, tablet). }\end{array}$ & .716 & .745 & & & \\
\hline $\begin{array}{l}\text { 11. I can write unique scenario for educational media (animation, video, } \\
\text { educational game). }\end{array}$ & .663 & .737 & & & \\
\hline 08. I can prepare online interactive lesson presentation. & .668 & .734 & & & \\
\hline 09. I can prepare different concept map and drawing on online. & 667 & .728 & & & \\
\hline $\begin{array}{l}\text { 10. I can build game with online game providers for both educational } \\
\text { and fun. }\end{array}$ & .673 & .720 & & & \\
\hline $\begin{array}{l}\text { 12. I can design a unique character for educational media (animation, } \\
\text { video, educational media). }\end{array}$ & .667 & .720 & & & \\
\hline 34. I can build an online platform to evaluate my students. & .803 & .715 & & & \\
\hline $\begin{array}{l}\text { 28. I can decide online platforms or simulation development app by } \\
\text { lesson content. }\end{array}$ & .772 & .705 & & & \\
\hline $\begin{array}{l}\text { 03. I can design a page/platform which students get lesson content with } \\
\text { social networks. }\end{array}$ & 623 & 688 & & & \\
\hline 35. I can plan process of mobile app development step by step. & .782 & 686 & & & \\
\hline 26. I can decide the computer hardware I use by my needs. & .711 & 681 & & & \\
\hline $\begin{array}{l}\text { 30. I can study with different simulation, virtual reality or augmented } \\
\text { reality apps. }\end{array}$ & .777 & 681 & & & \\
\hline 29. If needed, I can design simple simulations to use my lessons. & .761 & 677 & & & \\
\hline 33. I can develop websites about different departments. & .803 & .676 & & & \\
\hline $\begin{array}{l}\text { 06. I can prepare online survey, quiz etc. about whichever for my } \\
\text { students to fill. }\end{array}$ & 658 & 673 & & & \\
\hline 21. When I am online, I can understand which websites use & .713 & .671 & & & \\
\hline
\end{tabular}
technologies. 
36. I can survive the hardship in process of mobile app development. $\quad .741$

27. I can develop virtual reality app or augmented reality to enrich my .697 lessons.

31. I can re-enrich a printed lesson material with virtual reality or .756 augmented reality.

17. I can make brochure or poster with desktop publishing app (MS $\quad .637$

Publisher etc.).

38. I can prepare lesson content about mobile app development.

19. I can edit my images with photo editor app.

37. I can design creative interface design for my mobile app.

22. I can lonely install different operating systems (Windows, Linux, .682 MacOS).

20. I can know the formats (apx, php, html etc.) on address bar means.

47. I can enrich my lesson content by using electronic circuit (Arduino,

Raspberry Pi, Tinker Board, UDOO etc.).

46. I can build a project with electronic circuit (Arduino, Raspberry Pi, .496

Tinker Board, UDOO etc.).

45. I can decide components to be used in electronic circuit (Arduino, .496

Raspberry Pi, Tinker Board, UDOO etc.).

44. I can develop an app with electronic circuit (Arduino, Raspberry Pi, $\quad .497$

Tinker Board, UDOO etc.).

48. I can develop the products which support lesson content by using .478 electronic circuit (Arduino, Raspberry Pi, Tinker Board, UDOO etc.).

43. I can enrich my lesson content by using block-based app (Scratch, 364

Codu etc.)

42. I can develop lesson content by using educational robot kits.

59. I can mathematically express the solution ways of the problems I face in the daily life.

58.I think that I learn better the instructions made with the help of .600 mathematical symbols and concepts.

57. I think that I have a special interest in the mathematical processes.

66. I have problems in the issue of where and how I should use the variables such as $\mathrm{X}$ and $\mathrm{Y}$ in the solution of a problem.

63. It is fun to try to solve the complex problems.

62. I am good at preparing regular plans regarding the solution of the complex problems.

64. I make use of a systematic method while comparing the options at $\quad .577$ my hand and while reaching a decision.

67. I can apply the solution ways I plan respectively and gradually.

65. I have not problems in the demonstration of the solution of a .647 problem in my mind.

68. I can produce so many options while thinking of the possible .634 solution ways regarding a problem.

56. I can immediately establish the equity that will give the solution of a .582 problem.

60. In the cooperative learning, I think that I attain/will attain more .522 successful results because I am working in a group.

\begin{tabular}{|c|c|c|c|c|c|}
\hline 53. I like the people who are sure of most of their decisions. & .437 & & & & .790 \\
\hline 54. I like unbiased and realist people. & .386 & & & & .755 \\
\hline 52. Dreaming is caused to show up my important projects. & .358 & & & & .681 \\
\hline 51. I trust myself to conduct the plan while I plan to solve my problem. & .334 & & & & .674 \\
\hline $\begin{array}{l}\text { 55. I have faith in solving the problems when I come across a new } \\
\text { situation. }\end{array}$ & .322 & & & & .664 \\
\hline 50. I am easily adapted new technologies. & .300 & & & & .502 \\
\hline Eigenvalues & & 22.490 & 6.513 & 3.578 & 1.818 \\
\hline Explained Variance & & 29.488 & 13.835 & 12.221 & 6.999 \\
\hline
\end{tabular}

According to Table 2, the first factor of the scale consists of 30 items, the second factor consists of 7 items, the third factor consists of 12 and the fourth factor consists of 6 items. In the first factor, the factor loads ranges are between .785-.596 and have 22.490 eigenvalues in 
the scale and their contribution to total variance is 29.488. In the second factor, the factor loads ranges are in the range of .862-.670 and have 3.578 eigenvalues in the scale and its contribution to the total variance is 12.221 . In the third factor, the factor loads ranges are in the range of .846-.529 and have 6.513 eigenvalues in the scale and its contribution to the total variance is 13.835. In the fourth factor, the factor loads ranges are in the range of .790-.502 and have 1.818 eigenvalues in the scale and contribute 6.999 to the total variance. The items of each factor were analysed separately and factor names were determined. Within this framework, the first two factors were evaluated under the title of Production and the first factor consisting of 30 items was named as "Content Development" and the second factor consisting of 7 items was named as "Interactive Object Development". The remaining two factors were evaluated under Productive Thinking and the third factor consisting of 12 items was named as "Problem Solving" and the fourth factor consisting of 6 items was named as "Creativity".

\subsubsection{Item Factor Correlations}

With item-factor correlation analysis, the correlations between the scores of each factor and the items of that factor were calculated and its contribution to each factor was determined. The item-factor correlations results were analysed for each item and are presented in Table 3.

Table 3. Item Factor Correlations

\begin{tabular}{|c|c|c|c|c|c|c|c|}
\hline \multicolumn{4}{|c|}{ Production } & \multicolumn{4}{|c|}{ Productive Thinking } \\
\hline \multicolumn{2}{|c|}{ F1: Content Development } & $\begin{array}{l}\text { F2: Interactive } \\
\text { Development }\end{array}$ & \multirow[t]{2}{*}{ Object } & \multicolumn{2}{|c|}{ F3: Problem Solving } & \multicolumn{2}{|c|}{ F4: Creativity } \\
\hline Item & $\mathbf{r}$ & Item & & Item & $\mathbf{r}$ & Item & $\mathbf{r}$ \\
\hline$\overline{\mathrm{I} 14}$ & $.811^{* * *}$ & I47 & $.956 * *$ & I59 & $.841 * *$ & I53 & $.257 * *$ \\
\hline I13 & $.781 * *$ & I46 & $.958 * *$ & I58 & $.820 * *$ & I54 & $.228 * *$ \\
\hline $\mathrm{I} 25$ & $.809 * *$ & I45 & $.960 * *$ & I57 & $.804 * *$ & I52 & $.461 * *$ \\
\hline $\mathrm{I} 24$ & $.797 * *$ & I44 & $.951 * *$ & I66 & $.836 * *$ & I51 & $.461 * *$ \\
\hline I07 & $.765^{* *}$ & $\mathrm{I} 48$ & $.932 * *$ & I63 & $.796^{* *}$ & $\mathrm{I} 55$ & $.516^{* *}$ \\
\hline $\mathrm{I} 23$ & $.758 * *$ & I43 & $.853 * *$ & I62 & $.770 * *$ & I50 & $.573 * *$ \\
\hline I1 1 & $.723 * *$ & I42 & $.883 * *$ & I64 & $.771 * *$ & & \\
\hline I08 & $.716^{* *}$ & & & I67 & $.792 * *$ & & \\
\hline I09 & $.724 * *$ & & & I65 & $.756 * *$ & & \\
\hline I10 & $.717 * *$ & & & I68 & $.744 * *$ & & \\
\hline I12 & $.713 * *$ & & & I56 & $.699 * *$ & & \\
\hline I34 & $.812^{* * *}$ & & & I60 & $.604 * *$ & & \\
\hline I 28 & $.788 * *$ & & & & & & \\
\hline I03 & $.679 * *$ & & & & & & \\
\hline I35 & $.733 * *$ & & & & & & \\
\hline I 26 & $.790 * *$ & & & & & & \\
\hline I30 & $.775^{* *}$ & & & & & & \\
\hline I 29 & $.781^{* *}$ & & & & & & \\
\hline I33 & $.796 * *$ & & & & & & \\
\hline I06 & $.695 * *$ & & & & & & \\
\hline I 21 & $.736^{* * *}$ & & & & & & \\
\hline I36 & $.761 * *$ & & & & & & \\
\hline I27 & $.726^{* *}$ & & & & & & \\
\hline I31 & $.763 * *$ & & & & & & \\
\hline I17 & $.670 * *$ & & & & & & \\
\hline I38 & $.751 * *$ & & & & & & \\
\hline
\end{tabular}




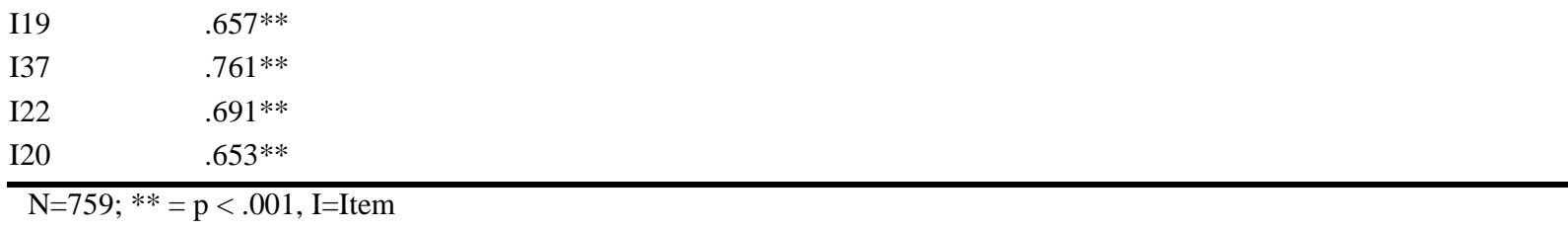

Table 3 shows that item-factor correlation values for the first factor are between .812 and .653 ; for the second factor are between .960 to .853 ; for the third factor are between .841 .604; and for the fourth factor are between .573 and .228. It is seen that each item has a significant and positive relationship with the total score of the factor to which it belongs ( $p<.001)$. According to these results, it can be said that each item serves the purpose of the factor to which it belongs.

\subsubsection{Item Distinctiveness}

In order to calculate the distinctiveness of the items, item scores were sorted from the largest to the smallest and upper and lower $27 \%$ groups were determined. Subsequently, independent sample t-test was applied to the 205 upper and lower group scores. Table 4 presents the t-values and statistical significance levels indicating the distinctiveness of the items.

Table 4. Item Distinctiveness

\begin{tabular}{|c|c|c|c|c|c|c|c|}
\hline \multicolumn{4}{|c|}{ Production } & \multicolumn{4}{|c|}{ Productive Thinking } \\
\hline \multicolumn{2}{|c|}{ F1: Content Development } & $\begin{array}{l}\text { F2: Interactive } \\
\text { Development }\end{array}$ & \multirow[t]{2}{*}{ Object } & \multicolumn{2}{|c|}{ F3: Problem Solving } & \multicolumn{2}{|c|}{ F4: Creativity } \\
\hline Item & $\mathbf{t}$ & Item & & Item & $\mathbf{t}$ & Item & $\mathbf{t}$ \\
\hline $\mathrm{I} 14$ & 27.072 & I47 & 24.054 & I59 & 14.198 & I53 & 5.058 \\
\hline I13 & 26.473 & I46 & 24.387 & I58 & 12.582 & I54 & 3.839 \\
\hline $\mathrm{I} 25$ & 28.163 & I45 & 24.436 & I57 & 12.480 & I52 & 11.613 \\
\hline I24 & 27.318 & I44 & 23.606 & I66 & 13.460 & I51 & 13.624 \\
\hline I07 & 26.125 & $\mathrm{I} 48$ & 22.741 & I63 & 11.450 & $\mathrm{I} 55$ & 8.584 \\
\hline I23 & 23.984 & I43 & 26.891 & I62 & 13.324 & $\mathrm{I} 50$ & 16.215 \\
\hline I1 1 & 20.828 & $\mathrm{I} 42$ & 26.635 & I64 & 14.138 & & \\
\hline I08 & 20.766 & & & I67 & 11.917 & & \\
\hline I09 & 20.526 & & & I65 & 11.793 & & \\
\hline I10 & 21.702 & & & I68 & 11.878 & & \\
\hline I12 & 21.797 & & & I56 & 11.528 & & \\
\hline I34 & 30.363 & & & I60 & 8.242 & & \\
\hline I 28 & 28.529 & & & & & & \\
\hline I03 & 19.916 & & & & & & \\
\hline I35 & 30.609 & & & & & & \\
\hline I26 & 23.274 & & & & & & \\
\hline I30 & 28.090 & & & & & & \\
\hline I29 & 26.715 & & & & & & \\
\hline I33 & 34.145 & & & & & & \\
\hline I06 & 20.818 & & & & & & \\
\hline I21 & 24.977 & & & & & & \\
\hline I36 & 25.241 & & & & & & \\
\hline I 27 & 23.506 & & & & & & \\
\hline I31 & 27.463 & & & & & & \\
\hline I17 & 20.049 & & & & & F1 & 48.419 \\
\hline I38 & 26.815 & & & & & F2 & 28.196 \\
\hline I19 & 19.241 & & & & & F3 & 16.709 \\
\hline
\end{tabular}


When Table 4 is analysed, it is seen that the values obtained as a result of independent sample t-test analysis for the total of 4 factors and 55 items vary between 34.145 and 3.839. The $t$ value for the total sum of the scale was determined as 55.671. The values obtained were significant $(p<.001)$. As a result of $t$ test, it can be said that the discrimination of each item and overall scale is high.

\subsection{Findings Regarding the Reliability of the Scale}

The data obtained were analysed with internal consistency and stability analysis to regarding the reliability of the scale. Findings and analysis steps are presented below.

\subsubsection{Internal Consistency Level}

Internal consistency and stability tests were used to determine the reliability of the whole scale and the four factors. For internal consistency coefficient, Cronbach Alpha value was considered. The reliability coefficient of .70 and above indicates that the scale is reliable (Kartal \& Dirlik, 2016). Scale reliability was also supported by Guttman Split-Half, Spearman-Brown tests and two paired semi-correlation formulas. Table 5 shows the analysis results of the scale and all factors.

Table 5. Reliability analysis results considering the whole of the scale and its factors

\begin{tabular}{lllllll}
\hline & Factors & $\begin{array}{l}\text { Numbe } \\
\mathbf{r} \\
\text { Items }\end{array}$ & $\begin{array}{l}\text { Two congruent } \\
\text { halves } \\
\text { correlation }\end{array}$ & $\begin{array}{l}\text { Spearma } \\
\text { n Brown }\end{array}$ & $\begin{array}{l}\text { Guttmann } \\
\text { Split-Half }\end{array}$ & $\begin{array}{l}\text { Cronbach' } \\
\text { Alpha }\end{array}$ \\
\hline \multirow{2}{*}{ Production } & F1: Content Development & 30 & .895 & .944 & .944 & .972 \\
Productive & F2: Int. Obj. Development & 7 & .921 & .959 & .944 & .973 \\
Thinking & F3: Problem Solving & 12 & .788 & .882 & .864 & .937 \\
\hline & F4: Creativity & 6 & .595 & .746 & .737 & .850 \\
\hline
\end{tabular}

As it is shown in the Table 5, it is composed of 4 factors in two dimensions and a total of 55 items. Two paired semi-correlations is .747; Spearman Brown reliability coefficient is .855; The Guttmann Split-Half value is .854 and the Cronbach's' Alpha reliability value is .972 . The two paired semi-correlations of the factors are from .895 to .595; Spearman Brown's values are from .944 to .746; The Guttmann Split-Half values are from .944 to .737; Cronbach's' Alpha values are from .972 to .850 . According to these results, it is concluded that the whole scale and each factor can make consistent measurements.

\subsubsection{Constancy Level}

Stability level of the scale was determined by test-retest method. For this purpose, the final 55-item scale was reapplied to the 24-person group after 4 weeks. In order to find the correlation values between the data groups obtained from the applications, both the whole scale and the related samples for each item were analysed using t-test method. The findings obtained from the analysis are given in Table 6. 
Table 6. Test-retest results of the items of the scale

\begin{tabular}{|c|c|c|c|c|c|c|c|}
\hline \multirow{2}{*}{\multicolumn{2}{|c|}{$\begin{array}{l}\text { Production } \\
\text { F1: Content Development }\end{array}$}} & \multicolumn{6}{|c|}{ Productive Thinking } \\
\hline & & \multicolumn{2}{|c|}{$\begin{array}{l}\text { F2: Interactive Object } \\
\text { Development }\end{array}$} & \multicolumn{2}{|c|}{ F3: Problem Solving } & \multicolumn{2}{|c|}{ F4: Creativity } \\
\hline Item & $\mathbf{r}$ & Item & $\mathbf{r}$ & Item & $\mathbf{r}$ & Item & $\mathbf{r}$ \\
\hline $\mathrm{I} 14$ & $.789 *$ & I47 & $.897 *$ & I59 & $.791 *$ & I53 & $.350 * *$ \\
\hline $\mathrm{I} 13$ & $.684 *$ & I46 & $.844 *$ & I58 & $.748 *$ & I54 & $.600 * *$ \\
\hline I25 & $.610^{*}$ & I45 & $.884 *$ & I57 & $.726 *$ & I52 & $.561 * *$ \\
\hline $\mathrm{I} 24$ & $.540 * *$ & I44 & $.835 *$ & I66 & $.865^{*}$ & I51 & $.354 * *$ \\
\hline I07 & .726 & I 48 & $.878 *$ & I63 & $.731 *$ & I55 & $.380 * *$ \\
\hline $\mathrm{I} 23$ & $.807^{*}$ & I43 & $.854 *$ & I62 & $.688 *$ & $\mathrm{I} 50$ & $.773 *$ \\
\hline I11 & $.736 *$ & I42 & $.829 *$ & I64 & $.432 * *$ & & \\
\hline I08 & $.723 *$ & & & I67 & $.559 *$ & & \\
\hline I09 & $.665^{*}$ & & & I65 & $.756^{*}$ & & \\
\hline I10 & $.694 *$ & & & I68 & $.365 * *$ & & \\
\hline $\mathrm{I} 12$ & $.572 * *$ & & & I56 & $.487 * *$ & & \\
\hline $\mathrm{I} 34$ & $.768 *$ & & & I60 & $.311 * *$ & & \\
\hline $\mathrm{I} 28$ & $.607^{*}$ & & & & & & \\
\hline I03 & $.729 *$ & & & & & & \\
\hline $\mathrm{I} 35$ & $.712 *$ & & & & & & \\
\hline I26 & $.627 *$ & & & & & & \\
\hline $\mathrm{I} 30$ & $.730 *$ & & & & & & \\
\hline I29 & $.650 *$ & & & & & & \\
\hline $\mathrm{I} 33$ & $.867 *$ & & & & & & \\
\hline I06 & $.866^{*}$ & & & & & & \\
\hline $\mathrm{I} 21$ & $.727 *$ & & & & & & \\
\hline $\mathrm{I} 36$ & $.715^{*}$ & & & & & & \\
\hline $\mathrm{I} 27$ & $.572 * *$ & & & & & & \\
\hline I31 & $.804 *$ & & & & & & \\
\hline I17 & $.585^{*}$ & & & & & F1 & $.854 *$ \\
\hline $\mathrm{I} 38$ & $.720 *$ & & & & & F2 & $.875 *$ \\
\hline I19 & $.559 * *$ & & & & & F3 & $.829 *$ \\
\hline I37 & $.629 *$ & & & & & F4 & $.507 * *$ \\
\hline $\mathrm{I} 22$ & $.670 *$ & & & & & Total & $.873 *$ \\
\hline $\mathrm{I} 20$ & $.837 *$ & & & & $\mathrm{~N}=24$; * & $; * * \mathrm{p}<.005$ & \\
\hline
\end{tabular}

Table 6 shows that the correlation coefficients obtained by the test-retest method of each item in the scale ranged between .31 and .897 , and each relationship was significant and positive. The correlation coefficients obtained by the test-retest method of the factors constituting the scale ranged from .507 to .875 . The correlation of total score was .873 and each relationship was significant and positive. Accordingly, it can be said that the scale can make stable measurements.

\section{Discussion and Conclusions}

As a result of this study, a scale was developed to determine the technological formation attitudes of teachers and teacher candidates. Technological Formation Scale was prepared as a 5-Likert-type scale. The scale consists of 55 items and 4 factors. Each item in the scale has the options which are Strongly Agree (5), Agree (4), Undecided (3), Disagree (2) and Strongly Disagree (1). The validity of the scale was determined by factor analysis and discriminant test. The exploratory factor analysis revealed that the scale consisted of 4 factors. 
These factors were evaluated under two headings: Production and Productive Thinking. The factors are respectively:

1. Production

- F1: Content Development

- F2: Interactive Object Development

2. Productive Thinking

- F3: Problem Solving

- F4: Creativity

Researchers have been carried out in the literature on Production and Productive Thinking topics, which are listed in the top headings of the mentioned factors. In the light of these studies, concepts related to production and thinking about production were examined. Thinking is defined as a functional feature of the mind that separates man from other living beings (Doğan, 2011). Productive Thinking is divided into five different operations by Guilford (1956): divergent thinking, evaluative thinking, cognition, convergent thinking, and memory. Using these five different processes, it is called Productive Thinking that the ideas and knowledge in the past or present produce new ideas or solutions to issues. It has also been shown that Guilford's theory of Productive Thinking is useful in making more effective decisions in engineering (Brown \& Katz 2009; NRC 2001). Hoffman \& Hoffman (1964) emphasised that productive thinking can include problem solving, analytic and logic dimensions such as creative thinking. At the same time under the headline of Productive Thinking, creativity has different definitions in the literature (Rouqette, 1992; Torrance, 1968; Stewig \& Vail, 1985; Turgut, 1993; Craft, 2003). According to Wegerif (2007), creativity is a fact that should be developed and maintained in the information age where information production environment exists. In this context, it can be said that Productive Thinking necessarily involves problem solving and creativity skills or facts.

The production title can be defined as the production of products after a number of processes. Technological materials used to embody the concepts or abstract concepts that are tried to be taught in education provide convenience (Gülen, 2010; Gülen \& Demirkuş, 2014). Therefore, it can be said that it is important that teachers and teacher candidates produce concrete products with interactive objects as well as information and communication technologies. The importance of material development was emphasized in the FATİH Project (MoNE, 2013). Thus, considering the developments in the literature, items and factors were created. Some items in the study were obtained from the items under the thinking dimension in the Computational Thinking Scale (CTS) developed by Korkmaz, Çakır and Özden (2017). These items were included in the factors under the head of Productive Thinking. As a result of the analysis, it was seen that other skills were distributed to other factors under the headings of production. Considering these findings in the literature, it can be said that the Productive Thinking has problem solving and creativity processes, and the production has content creation with development materials.

To determine the construct validity of the scale, eigenvalues, factor loads of factor items, and variance amounts were calculated and the construct validity of the scale can be said to be appropriate in line with the results obtained. With item-factor correlation analysis, the correlation between each factor and the items of that factor were calculated and their contribution to the factor in which each item was included was determined. According to these results, it can be said that each item is compatible with the factor and scale in which it is included and has a significant contribution. For the calculation of the discrimination of items, 
the points of the items have been descending sort, set upper $27 \%$ and lower $27 \%$ groups, and independent sample t-test was applied to these lower and upper group scores. According to the result of the t-test, it was determined that the whole scale and the items had a high level of discrimination. To determine the reliability of the whole scale and the four factors identified, stability tests and internal consistency were used. The internal consistency coefficient was evaluated by Cronbach Alpha value. In addition, internal consistency coefficients were calculated by Guttman Split-Half, Spearman-Brown tests and two paired semi-correlation formulas. When the results of the analysis are examined, it is concluded that the whole scale and each factor can make consistent measurements.

In the literature, similar scale studies on this subject have been found in the literature. (Schmidt et al., 2009; Kaya \& Dă̆, 2013; Kaya et al., 2013; Haciömeroğlu, 2014; Graham et al., 2009; Timur \& Taşar, 2011; Öztürk \& Horzum, 2011; Horzum, 2011; Kuşkaya-Mumcu, 2011; Gökçek \& Yılmaz, 2019; Lee \& Tsai, 2010; Usta \& Karakuş, 2016; Hiçy1lmaz, 2018, Özel et al., 2013). When the scales are examined, it is determined that the scales are field dependent or related to utilization cases rather than production in technology. In this scale development study, to measure the ability of teachers and teacher candidates to produce content using educational technologies is aimed. The biggest factor that makes it necessary to measure the ability to produce content is the developments in technology and its reflections on educational technologies (Yağc1, 2011; Carver, 2016; An \& Williams, 2010). Therefore, it is believed that this scale development study will contribute to technology studies, especially in education in the literature.

Factor analysis findings obtained as a result of the study show that Technological Formation Scale is a valid and reliable measurement tool. With the use of the TFS, it will be possible to examine the technological formation of teachers and prospective teachers in a way which includes the competence of producing content such as making a website with web 2.0 technologies. It is thought that the results of the scale will be able to use the appropriate technology for the purposes of education and training activities with both pre-service and inservice supports to teachers and candidate teachers.

\section{References}

Adigüzel, T., Gürbulak, N., \& Sariçayir, H. (2011). Smart boards and their instructional uses. Mustafa Kemal University Journal of Social Sciences Institute, 8(15).

Al-Qallaf, C. L., \& Ridha, A. (2018). A comprehensive analysis of academic library websites: design, navigation, content, services, and web 2.0 tools. International Information \& Library Review, 51(2), 93-106. doi: 10.1080/10572317.2018.1467166

Alexander, B., \& Levine, A. (2008). Web 2.0 storytelling: Emergence of a new genre. EDUCAUSE Review, 43(6), 40-56.

An, Y. J., Williams, K. (2010). Teaching with web 2.0 technologies: Benefits, barriers and lessons learned. International Journal of Instructional Technology and Distance Learning, 7(3), 41-48.

Balc1, A. (2009). Sosyal bilimlerde araştırma: Yöntem, teknik ve ilkeler. [Research in social sciences: Methods, techniques and principles]. Ankara: PegemA Pub.

Bakioğlu, A, \& Şentuna, T. (2001). İnternet ile eğitimde öğretmen ve okul yöneticilerinin görevleri (Duties of teachers and school administrators in internet education). Pamukkale University Journal of Education, 9 (9), 10-18.

Brown, T., \& Katz, B. (2009). Change by design: How design thinking transforms organizations and inspires innovation. New York, NY: Harper Collins. 
Bulman, G., \& Fairlie, R. W. (2016). Technology and education computers, software, and the internet. Cambridge, MA: National Bureau of Economic Research.

Büyüköztürk, Ş., 2002. Factor analysis: basic concepts and Using to development scale. Educational Administration in Theory \& Practice, 32, 470-483.

Büyüköztürk, Ş. (2006). Sosyal bilimler için veri analizi el kitabı. [Manual of data analysis for social sciences. Ankara: Pegem Academy]. Ankara: Pegem Akademi

Büyüköztürk, Ş., Kılıç Çakmak, E., Akgün, Ö. E., Karadeniz, Ş. \& Demirel, F. (2016). Bilimsel araştırma yöntemleri. [Scientific research method. Ankara: Pegem Academy]. Ankara: Pegem Akademi

Carver, L. B. (2016). Teacher perception of barriers and benefits in K-12 technology usage. Turkish Online Journal of Educational Technology-TOJET, 15(1), 110-116.

Cox, S., \& Graham, C. R. (2009). Diagramming TPACK in practice: Using an elaborated model of the TPACK framework to analyze and depict teacher knowledge. TechTrends, 53(5), 60-69. doi: 10.1007/s11528-009-0327-1

Craft, A. (2003). Creative thinking in the early years of education. Early Years, 23(2), 143154. doi: 10.1080/09575140303105

Doğan, N. (2011). Yaratıcı düşünme ve yaratıcılı [Creative thinking and creativity]. Ĕgitimde yeni yönelimler [New directions in education]. Ankara: Pegem Akademi, 167-198.

Eroğlu, A. (2008). Faktör analizi, SPSS uygulamalı çok değişkenli istatistik teknikleri [Factor analysis, SPSS multivariate statistical techniques], Ankara: Asil Publishers, 321-331.

Fraenkel, J.R. \& Wallen, N.E. (2006). How to desing and evaluate research in education. New York: McGaw-Hill International Edition.

Hoffman, M. L., \& Hoffman, L. W. (1964). Review of child development research. New York: Russell Sage Foundation. 349-381.

Gökçek, T., \& Y1lmaz, A. (2019). The adaptation of the pedagogical knowledge and skills survey into Turkish: Validity and reliability study. Turkish Journal of Education, 5470. doi: 10.19128/turje. 459678

Graham, C.R., Burgoyne, N., Cantrell, P.P., Smith, L.K., \& Harris, R. (2009). TPACK development in science teaching: measuring the TPACK confidence of inservice science teachers. (2009). TechTrends, 53(5), 70-79. doi: 10.1007/s11528-009-0328-0

Grosseck, G. (2009). To use or not to use web 2.0 in higher education?. Procedia - Social and Behavioral Sciences. 1(1), 478-482.

Guilford, J.P. (1956) The structure of intellect. Psychological Bulletin, 53, 267-293. http://dx.doi.org/10.1037/h0040755

Gülen, S. (2010). The study development visual course materials containing popular physics concepts. Unpublished dissertation, Yüzüncü Y1l University Graduate School of Natural and Applied Sciences. Van.

Gülen, S., \& Demirkuş, N. (2014). The effects of visual material on students' achievement in "the solar system and beyond: mystery of space" unit. Saarbrücken: Türkiye Alim Pub.

Hacıömeroğlu, G., Şahin, Ç., \& Arcagök, S. (2014). Turkish adaptation of preservice teachers' technological pedagogical content knowledge assessment instrument. Journal of Theory and Practice in Education, 10(2), 297-315.

Hiçyılmaz, Y. (2018). Self-efficacy of technical pedagogical content knowledge of visual arts teacher candidates. Unpublished doctoral dissertation. Ondokuz Mayıs University Graduate School Of Educational Sciences, Samsun.

Horzum, M. B. (2011). Examining computer game addiction level of primary school students in terms of different variables. education and science, 36(159). 
Hu, C. \& Fyfe, V. (2010). Impact of a new curriculum on pre-service teachers' technical, pedagogical and content knowledge (TPACK). In Proceedings of ASCILITE Australian Society for Computers in Learning in Tertiary Education Annual Conference 2010 (pp. 184-189). Australasian Society for Computers in Learning in Tertiary Education. Retrieved November 16, 2019 from https://www.learntechlib.org/p/45386/.

Kalaycı Ş. (2010). Spss uygulamalı çok değişkenli istatistik teknikleri. [Applied multivariate statistical techniques. Ankara: Asil Publishing Distribution]. Ankara: Asil Pub..

Kaya, S., \& Dağ, F. (2013). Turkish adaptation of technological pedagogical content knowledge survey for elementary teachers. Educational Sciences: Theory \& Practice, 13(1), 291-306.

Kaya, Z., Kaya, O. N. \& Emre, İ. (2013). Adaptation of technological pedagogical field knowledge scale to Turkish. Educational Sciences: Theory \& Practice, 13(4), 23552377.

Koehler, M., \& Mishra, P. (2009). What is technological pedagogical content knowledge (TPACK)?. Contemporary Issues in Technology and Teacher Education, 9(1), 60-70.

Korkmaz, Ö., Çakir, R., \& Özden, M. Y. (2017). A validity and reliability study of the computational thinking scales (CTS). Computers in Human Behavior, 72, 558-569. doi: 10.1016/j.chb.2017.01.005

Kula Kartal, S., \& Mor Dirlik, E. (2016). Historical development of the concept of validity and the most preferred technique of reliability: cronbach alpha coefficient. Abant İzet Baysal University Journal of Faculty of Educational, 16(4), 1865-1879.

Kuşkaya-Mumcu, F. (2011). Effectiveness of ICT integration instruction provided to student teachers in a networked learning environment. Unpublished doctoral dissertation, Hacettepe University Graduate School of Natural and Applied Sciences. Ankara.

Lee, M.-H., \& Tsai, C.-C. (2008). Exploring teachers' perceived self efficacy and technological pedagogical content knowledge with respect to educational use of the World Wide Web. Instructional Science, 38(1), 1-21. doi: 10.1007/s11251-008-90754

Mcknight, K., Omalley, K., Ruzic, R., Horsley, M. K., Franey, J. J., \& Bassett, K. (2016). teaching in a digital age: how educators use technology to improve student learning. Journal of Research on Technology in Education, 48(3), 194-211. doi: 10.1080/15391523.2016.1175856

Ministry of National Education (2013). Ilköğretim kurumları (ilkokullar ve ortaokullar) fen bilimleri dersi (3,4,5,6,7 ve 8. Sinıflar) ögretim programı (Primary education institutions (primary and secondary schools) science courses (3,4,5,6,7 and 8th grades) curriculum). Ankara: Board of Education and Training.

Ministry of National Education, Teacher Training and Development Directorate. (2017). Öğretmenlik mesleği genel yeterlikleri [General competencies of teaching profession]. Retrieved from: https://oygm.meb.gov.tr/meb_iys_dosyalar/2018_06/29111119_TeachersGeneralCom petencies.pdf

Mishra, P., \& Koehler, M. J. (2006). Technological Pedagogical Content Knowledge: A Framework for Teacher Knowledge. Teachers College Record, 108(6), 1017-1054. doi: 10.1111/j.1467-9620.2006.00684.x

Moradi-Rekabdarkolaei, S. (2011). The Comparison of ICT' literacy between teachers and students and presenting a model for development of ICT in schools. Journal of Turkish Science Education. 8(4), 43-54.

National Research Council. (2001). Theoretical foundation for decision making in engineering design. Washington, DC: The National Academies Press. 
Okello-Obura, C., \& Ssekitto, F. (2015). Web 2.0 technologies application in teaching and learning by makerere university academic staff. Library Philosophy and Practice (ejournal). 1248. http://digitalcommons.unl.edu/libphilprac/1248

Önal, N. (2016). Development, validity and reliability of tpack scale with pre-service mathematics teachers. International Online Journal of Educational Sciences, 8(2), 93107.

Özel, M., Timur, B., Timur, S. \& Bilen, K. (2013). The adaptation of students' perceptions of college teachers' pedagogical content knowledge questionnaire into Turkish. Ahi Evran University, Journal of Kırşehir Education Faculty, 14(1), 407-428.

Özden, M. Y. (n.d.). Teknolojik formasyon? Ne olabilir ki? [technological formation? What could it be?] Retrieved from http://myozden.blogspot.com/2012/01/teknolojikformasyon-ne-olabilir-ki.html.

Özden, M. Y. (n.d.). Computational thinking = Bilgisayarca düşünme becerileri?. [Computational thinking $=$ Computational thinking skills?] Retrieved from http://myozden.blogspot.com.tr/2015/06/computational-thinking-bilgisayarca.html.

Öztürk, E., \& Horzum, M. B. (2011). Adaptation of technological pedagogical content knowledge scale to Turkish. Journal of Kirsehir Education Faculty, 12(3).

Palaigeorgiou, G., \& Grammatikopoulou, A. (2016). Benefits, barriers and prerequisites for web 2.0 learning activities in the classroom. Interactive Technology and Smart Education, 13(1), 2-18. doi: 10.1108/itse-09-2015-0028

Rahimi, E., Berg, J. V. D., \& Veen, W. (2015). Facilitating student-driven constructing of learning environments using web 2.0 personal learning environments. Computers \& Education, 81, 235-246. doi: 10.1016/j.compedu.2014.10.012

Rouquette, Michel-Louis. (1992). Creativity. Trans. Işın Gürbüz." İstanbul: İletişim Pub.

Russell, D. W. (2002). In search of underlying dimensions: The use (and abuse) of factor analysis in personality and social psychology bulletin. Personality and Social Psychology Bulletin, 28(12), 1629-1646. doi: 10.1177/014616702237645

Sarı, M. H., \& Bostancıoğlu, A. (2018). Application of technological pedagogical content knowledge framework to elementary mathematics teaching: A scale adaptation study. Journal of Theoretical Educational Science, 11, 296-317.

Sarıtepeci, M., Durak, H., \& Seferoğlu, S. S. (2016). Examination of teachers' in-service training needs in the field of instructional technology: an evaluation in light of applications implemented at FATIH project. Turkish Journal of Computer and Mathematics Education (TURCOMAT), 7(3), 601-601.

Schmidt, D. A., Baran, E., Thompson A. D., Koehler, M. J., Mishra, P. \& Shin, T. (2009-10). Technological pedagogical content knowledge (TPACK): The Development and Validation of an Assessment Instrument for Preservice teachers. Journal of Research on Technology in Education, 42(2), 123-149.

Shulman, L. (1987). Knowledge and teaching: foundations of the new reform. Harvard Educational Review, 57(1), 1-23. doi: 10.17763/haer.57.1.j463w79r56455411

Shulman, L. S. (1986). Those who understand: knowledge growth in teaching. Educational Researcher, 15(2), 4. doi: 10.2307/1175860

Stewig, J. W., \& Vail, N. J. (1985). The relation between creative drama and oral language growth. The Clearing House: A Journal of Educational Strategies, Issues and Ideas, 58(6), 261-264. doi: 10.1080/00098655.1985.9955556

Tatlı, Z., İpek Akbulut, H., \& Altınışık, D. (2016). The impact of web 2.0 tools on pre-service teachers' self confidence levels about TPACK. Turkish Journal of Computer and Mathematics Education (TURCOMAT), 7(3), 659-659.

Tekin, A, \& Polat, E. (2014). Technology policies in education: Turkey and several other countries. Journal of Theory and Practice in Education, 10 (5), 1254-1266. 
Thomas, M., \& Thomas, H. (2012). Using new social media and web 2.0 technologies in business school teaching and learning. Journal of Management Development, 31(4), 358-367. doi: 10.1108/02621711211219013

Timur, B., \& Taşar, M. F. (2011). The adaptation of the technological pedagogical content knowledge confidence survey into turkish. Gaziantep University. Journal of Social Sciences, 10(2), 839 -856.

Torrance, E. P. (1968). Education and the creative potential. Minneapolis, Ma: Univ. of Minnesota Press.

Turanlı, M., Taşpınar Cengiz, D., Bozkır, Ö. (2014). Ranking of provinces according to success status in university entrance exams by factor analysis. Istanbul University Econometrics and Statistics e-Journal, 17, 45-68. Retrieved from http://dergipark.org.tr/iuekois/issue/8995/112129

Turgut İ. (1993). Sanat felsefesi. [Philosophy of Art. İzmir: University Bookstore]. İzmir: Üniversite Kitabevi.

Usta, M. E., \& Karakuş, M. (2016). The development of the scale of pedagogical literacy. Kastamonu Education Journal, 24(1), 133-146.

Voogt, J., \& Mckenney, S. (2016). TPACK in teacher education: are we preparing teachers to use technology for early literacy? Technology, Pedagogy and Education, 26(1), 6983. doi: 10.1080/1475939x.2016.1174730

Wegerif, R. (2007). Teaching thinking: Metaphors and taxonomies. Dialogic Education and Technology, 125-157. doi: 10.1007/978-0-387-71142-3_7

Yağcı Y., (2009). Web teknolojisinde yeni bilgi firtınası: Web 3.0. [New information storm in web technology. UNAK Existence in the Information Age: "Opportunities and Threats" Symposium, Istanbul: Yeditepe University Proceedings Book]. ÜNAK Bilgi Çağında Varoluş: "Fırsatlar ve Tehditler" Sempozyumu, İstanbul: Yeditepe Üniversitesi Bildiriler Kitabı.

Yllayaz, Ö., \& Kaya, Z. (2013). Technology integration models in teacher education and technological pedagogical content knowledge. Western Anatolia Journal of Educational Sciences, 4(8). 57-83 